\title{
EFFECT OF COLD STORAGE USING SOLAR ENERGY ON QUAILTY OF POMEGRANATE FRUITS
}

\author{
Ahmed E. Suliman' ${ }^{1}$; Yousry. B. Abd Elhay ${ }^{2}$; Kassem, M. A A $^{3}$, and \\ Heba G. R.Youns ${ }^{4}$
}

\begin{abstract}
This study aims to evaluate a cold storage system using solar energy of pomegranate fruits (cv. Wonderful) for storage period 50 days under storing temperatures of $\left(5^{\circ} \mathrm{C}\right)$ and relative humidity of $90-95 \%$. The storage process was done using two refrigeration systems one of them is a refrigerator driven by solar energy, the other one driven using electrical energy. The component of refrigerator driven by solar energy consists, two parallel photovoltaic cells $(P V)$, two batteries, an inverter, and cables, In addition to refrigerator unit. Testing the PV system showed that, nine hours discharge time for one battery is available during connected to the cold storage. So it is necessary to use two batteries connected in series to be suitable for refrigerator driven power and Egyptian conditions, and can therefore run the cooling system throughout the day without interruption. The percentage of weight loss, hardness, and total soluble solid (TSS) for pomegranate fruits using refrigerator driven using photovoltaic cell were $8.46 \%, 11.18 \mathrm{~kg}_{f}$, and $15.80 \%$ respectively; Meanwhile cold storage driven by electrical energy, these parameters were $8.79 \%, 10.41 \mathrm{~kg}_{f}$, and $15.71 \%$ respectively. Operating cost using solar energy achieved the lowest cost compare with using electrical energy, therefore, can rely on the use of solar energy instead of electrical energy to operate the refrigeration unit. From the above results, pomegranate fruit inside $P V$ driven refrigerator has a good quality compared with pomegranate fruit inside electrically driven refrigerator.
\end{abstract}

Keywords: pomegranate, quality, cold storage, solar energy.

\footnotetext{
${ }^{1}$ Professor of Agricultural Engineering, Fac. Agric., Cairo University.

${ }^{2}$ Assistant Prof., Agric. Eng. Dept., Fac. Agric., Cairo University.

${ }^{3}$ Assoc. Prof., Mechanical Power, Dept., Fac. Engineering, Cairo Univ.

${ }^{4}$ Demonstrator, Agric. Eng., Fac. Agric. Cairo University.
} 


\section{INTRODUCTION}

$\mathrm{P}$ omegranate (Punica granatum L.) is one of the oldest known edible fruit belonging to Punicaceae family. To date, pomegranate is widely grown in areas such as Iran, India, Egypt, Lebanon, China, Spain, France, USA, Israel, and most recently South Africa (Mphahlele et al ,, 2014). Pomegranate fruit is known as a highly nutritional fruit, consisting of considerable amount of sugars, vitamins, polysaccharides and important minerals (Miguel et al., 2010). In addition, the fruit contains several important medicinal ingredients that are beneficial to human health. Such ingredients include several groups of phytochemical compounds, (Fawole et al., 2012). Pomegranate is one of the major horticultural crops in Egypt. Horticultural Res. Ins., (2014) reported that the cultivated area is 13.521 thousand feddans in 2012. The total annual production in Egypt is about 64574 tons in 2012. Darwesh $\boldsymbol{e t}$ al. (2010) defined refrigeration as the branch of science that deals with the process of reducing and maintaining the temperature of a space or material below the temperature of the surroundings. Precooling and refrigerated storage have been widely reported as effective techniques to preserve fruit quality and freshness after harvest, as these techniques tend to reduce the rate of biochemical reactions and microbiological growth Ngcobo et al. (2013). While Ekrami-Rad et al. (2011) mentioned that storage temperature, humidity, and duration have a considerable effect on changes in fruit's quality and mechanical properties. Storage of fresh horticultural products after harvest is one of the most pressing problems of a tropical country like Egypt (Basediya et al. 2013). Shelf-life of pomegranate arils is shorter than whole fruit. While the latter can be stored for 3-4 months at temperatures below $10{ }^{\circ} \mathrm{C}$ (Fawole and Opara, 2013) pomegranate arils can last for a period of 1 - 2 weeks when stored under $5{ }^{\circ} \mathrm{C}$ (Caleb et al., 2013). Qenawy et al. (2004) mentioned that approximately $15 \%$ of all electricity produced worldwide is used for refrigeration and air conditioning processes as estimated by the International Institute of Refrigeration (IIR). The solar atlas indicates that Egypt, as one of the sun-belt countries, is endowed with high intensity direct solar radiation of $2000-3200 \mathrm{~kW} . \mathrm{h} / \mathrm{m}^{2}$.year from north to south (Khalil et al., 2010), On other hand, applying the solar cooling systems 
can reduce the electricity peak loads, purchased electricity from the utility companies and also it can reduce the environmental problems (Hamed, 2013). This research aimed to evaluate the effect of cold storage using a solar refrigeration system in comparing with cold storage using electrical energy to preserve of pomegranate fruits.

\section{MATERIALS AND METHODS}

Pomegranate fruits (cv. Wonderful) were harvested during October from Regoa farm at Egypt -Alexandria desert Road (64 Km from Cairo) and transferred to the laboratory of agriculture engineering department, Faculty of Agriculture, Cairo University, Giza which lies at latitude $\left(30^{\circ}\right.$ $\mathrm{N}$, and longitude $31.20^{\circ} \mathrm{E}$ ), fruit were washed and dried themfruits were selected for the determination of physic-chemical and mechanical properties. Fruit samples were packed inside open carton boxes with the following dimensions: length and width $(300 \mathrm{~mm})$, and $(150 \mathrm{~mm})$ height, fruits were randomly divided into two groups and stored at two refrigerator, the first refrigerator is a photovoltaic cell (PV) driven, the second is electrically driven. Fruits stored at $5{ }^{\circ} \mathrm{C}$ with relative humidity 90-95\%. Some physical and mechanical such as Weight loss, hardness, and total soluble solid was evaluated during storage periods in both cold storages. Pomegranate fruits were sampled at 10 days interval over a period of 50 days.

Experiments were carried out using solar energy in vapor compression refrigeration and compared with cold storage using electrical energy to study the effect of cold storage for some physical and mechanical properties for pomegranate. Pomegranate fruits stored at temperature $5{ }^{\circ} \mathrm{C}$ and relative humidity of $90-95 \%$ for 50 days.

\section{Description of solar and electrical refrigeration systems}

The solar refrigeration system was designed, fabricated and tested in agricultural engineering department, faculty of agriculture, Giza, Egypt. The system required power of photovoltaic cells to run the vapor compression refrigerator from calculation it needs 417.6 watt approximately 500 watt (2 panel ) connected in parallel to obtain the 
desired voltage and current. Two battery connected series, (12 V-100Ah for each battery) were charged by solar PV array during daytime and used to supply power to the load as needed. An inverter $(2 \mathrm{~kW})$ was used to convert the direct current (DC) and supplied with adapter for the effort provide regulator to maintain the battery voltage under the technical specifications of each. Solar panel and battery electricity into singlephase alternating current AC electricity. All electrical wires used in the system were $40 \mathrm{~mm}$ diameter to keep the voltage loss of the PV panels.

Two Vapor compression refrigerator were used, the first driven by solar energy and the second driven through network electrical energy, and have the same of specifications which are $(470 \times 400 \times 800)$ dimensions $\mathrm{mm}$ and Consumption $0.5 \mathrm{~kW}$. h/ $24 \mathrm{~h}$.

\section{Measurements}

\section{- Electric supply voltage of refrigerator}

The voltage output from invertor in the PV driven refrigerator, and the electric network supply voltage were measured by using digital multimeter (DT-9205A made in China).

The actual refrigeration capacity (ARC) calculated by the following equation, assuming constant refrigerator coefficient of performance, power factor and electric resistance.

$$
A R C=\frac{Q_{\text {ref }_{i} \text { elec }}^{*}}{Q_{\text {ref }, \text { Nom }}}=\left(\frac{\text { Volt }_{\text {elec }}}{\text { Volt }_{\text {nom }}}\right)^{2}
$$

Where: (ARC) ratio between actual refrigeration capacity $\left(\mathrm{Q}_{\text {ref,elec }}\right)$ and nominal refrigeration capacity $\left(\mathrm{Q}_{\text {ref,Nom }}\right),\left(\right.$ Volt $\left._{\text {elec }}\right)$ actual voltage (Volt $\left.{ }_{\text {nom }}\right)$ nominal rated voltage.

\section{- Internal temperatures of refrigerators}

Data logger connected with two thermocouples, were used to measure the instantaneous internal air temperature in the two refrigerators (220T8, Huato, Shenzhen, China).

\section{- Weight loss of fruits}

Pomegranate fruits weights were determined using an electronic balance having accuracy of 0.01g. (EQ-1200 made in Taiwan). 
The weight loss of pomegranate fruits can be calculated by the following equation (Hussein et al., 2015):

$$
\mathrm{W}_{\mathrm{L}}=\frac{\left(\mathrm{W}_{\mathrm{i}}-\mathrm{W}_{\mathrm{f}}\right)}{\mathrm{W}_{\mathrm{i}}} \times 100
$$

Where, $\mathrm{W}_{\mathrm{L}}=$ Cumulative weight loss $\%$ of fruit, $\mathrm{W}_{\mathrm{i}}=$ Initial weight $(\mathrm{g})$ of the fruit at the beginning of storage and $\mathrm{W}_{\mathrm{f}}=$ Final weight $(\mathrm{g})$ of the fruit at the time of sampling during storage.

- Fruits hardness

Pomegranate fruits hardness $\left(\mathrm{kg}_{\mathrm{f}}\right)$ was measured using a hand penetrometer (Fruit pressure tester FT327) with a head of a flat- end probe $(3.0 \mathrm{~mm}$ diameter) which measures the penetration resistance of pomegranate fruits, which was the force required for pushing a probe into a product to a depth that causes irreversible crushing. It was given as an indicator of the mechanical strength and better keeping quality of pomegranate.

\section{- Total soluble solids}

Total soluble solids percentage (TSS) were determined by squeezing the Juice from fresh pomegranate tissues using a garlic press onto digital refractometer (Atago, Tokyo, Japan) with accuracy of (0-53) \% as described in A.O.A.C. (1995).

\section{- The cost of cold storage}

The economic study is conducted to determine the cost of cold storage using solar and electrical energy. The investment the investment cost of each component constituting the system is presented in table (1)

Many assumptions are taken into account during the calculated:

- The system expectancy is 20,10, 8 and 5 years for PV module, refrigerator unit, inverter and storage battery respectively.

- The capital cost estimate for all options is based on local prices for the equipment.

- The maintenance and operating expenses are estimated at $10 \%$ of the capital cost for electrical refrigerator and $1 \%$ for solar refrigerator.

- The interest rate and taxes ratio were taken as $7 \%$ and $3 \%$ respectively. 
The hourly cost of both solar and electrical refrigeration can be calculated according to the following formula (EL-Awady et al., 2015):

$$
C=\frac{p}{h}\left[\frac{1}{e}+\frac{i}{2}+t+r\right]+[h p \times s]+\left(\frac{W}{144} \times 0.1\right)
$$

Where,(C) Cost LE/hr, (P) Capital investment for handling machine, (h) Yearly operating hours for handling machine, (e) Life expectancy for equipment in general, (i) Interest rate, (t)Taxes and overheads ratio, (r) Maintenances and repairs ratio investment, (hp) Power of electric motor, (S) Power unit price, (W) Labor wag rate per month.

\begin{tabular}{lll}
\multicolumn{3}{l}{ Table 1. Description and costs of the components of the present } \\
solar treatment system, 2016. \\
\hline Comments & Specification & Total cost (L.E) \\
\hline Photovoltaic cell & $(2 \times 250)$ watt & 3000 \\
Inverter & 2 k watt, 220 volt & 2000 \\
Battery & $(2 \times 12 \mathrm{~V}-100 \mathrm{~A})$ & 2500 \\
Cables and wire & $40 \mathrm{~mm}$ & 260 \\
Refrigerator unit & 87 watt & 1240 \\
Lamination & 2 lamps with 10 watt & 10 \\
\hline $\begin{array}{l}\text { Total costs of } \\
\text { construction }\end{array}$ & Present system & 9010 \\
\hline
\end{tabular}

\section{RESULTS AND DISCUSSION}

\section{Performance of solar cold storage and electrical unit}

a. The output voltage from both electric network and inverter

Table (2) and figure (1)show the variation of supply volt to each refrigerator, the voltage output from electric network supply (electrical volt) (EV) in day 8/1/2016, and the output voltage from inverter in solar cell system that used to operate the refrigerator unit of solar panels (SV). The PV driven refrigerator almost supplied with constant 220 volt all day. While the electrically driven one the supply volt. 
Table. 2. Voltage output from electric network and output from inverter

\begin{tabular}{ccc}
\hline Time & Voltage of EV & Voltage of SV \\
\hline 9:00 AM & 178 & 220 \\
10:00 AM & 189 & 220 \\
11:00 AM & 194 & 220 \\
noon & 179 & 220 \\
1:00 PM & 186 & 220 \\
2:00 PM & 188 & 220 \\
3:00 PM & 186.8 & 220 \\
4:00 PM & 181.3 & 220 \\
5:00 PM & 180.6 & 220 \\
6:00 PM & 177.9 & 220 \\
7:00 PM & 176.4 & 220 \\
8:00 PM & 197.4 & 220 \\
9:00 PM & 181.9 & 220 \\
\hline
\end{tabular}

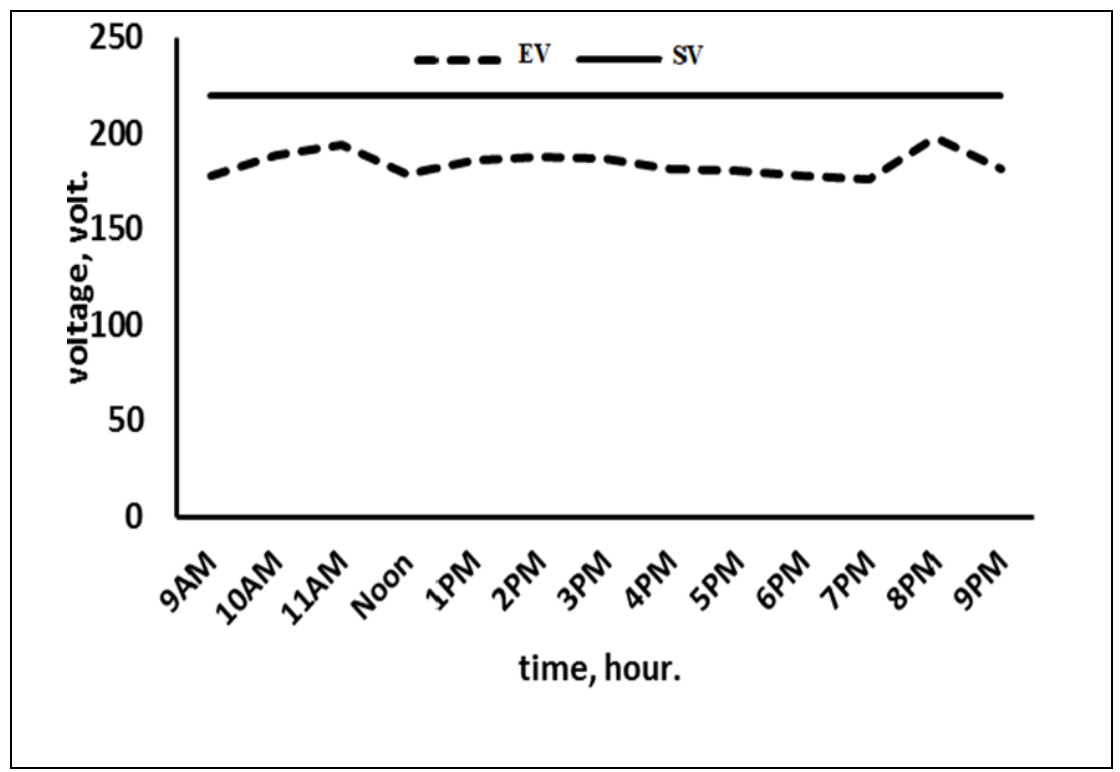

Fig. 1. Voltage Output from invertor in solar system and electric network supply.

The average supply volt around the day is (184.3) volt. By using equation (1) the actual refrigeration capacity of cold storage using solar 
energy equal to 1 , but the actual refrigeration capacity of cold storage using electrical energy equal to 0.7 of nominal capacity. These result indicated that cold storage using solar energy keep the pomegranate fruits with a good quality.

\section{b. Internal temperatures of refrigerators}

Figure (2) shows the variation of internal temperatures in each refrigerator. Figure (2) indicated that there were variation in internal temperatures using in each refrigerator driven solar energy $\left(\mathrm{T}_{\mathrm{SR}}\right)$ and electrical energy $\left(\mathrm{T}_{\mathrm{ER}}\right)$.

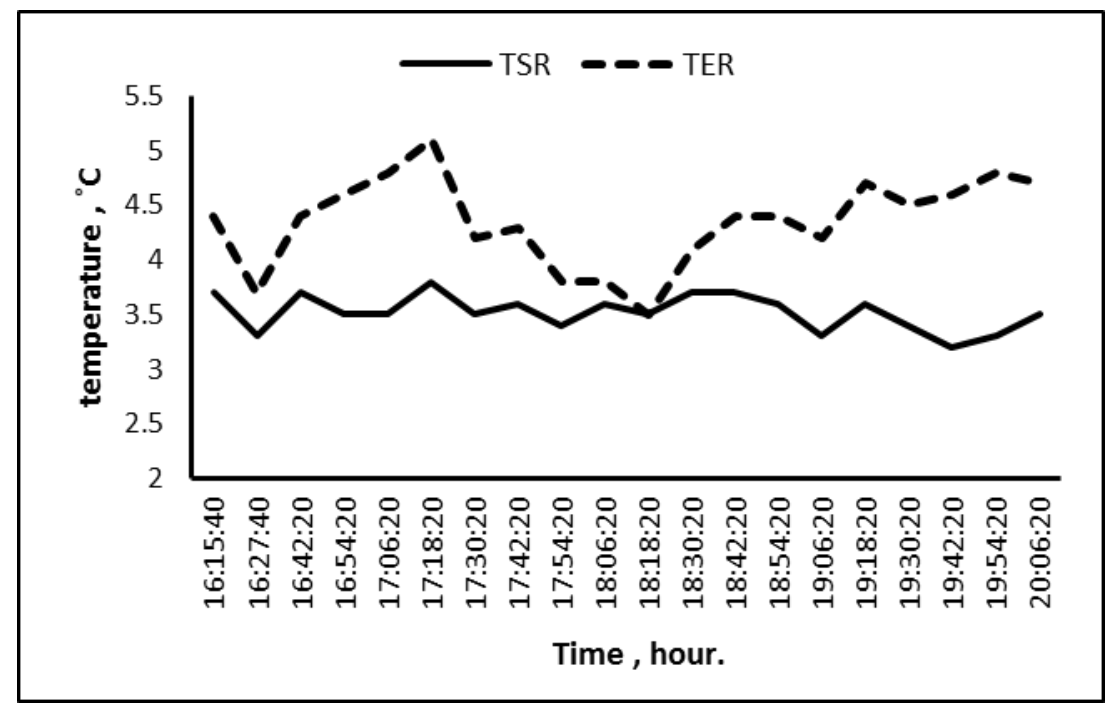

Fig. 2. Temperatures of refrigerator driven with solar and electrical energy.

The variation of internal temperatures using refrigerator driven solar energy was $0.9{ }^{\circ} \mathrm{C}$, while the variation of internal temperatures using refrigerator driven electrical energy was $1.9{ }^{\circ} \mathrm{C}$. These variation effects on the quality of pomegranate fruits stored.

\section{Physical and mechanical properties of pomegranate fruit} during cold storage.

- Weight loss of fruits

Table (3) shows, the percentage of cumulative weight loss for pomegranate fruits during cold storage using solar energy and electrical energy (EE) over 50 days of storage period. Pomegranate fruits were 
highly susceptible to weight loss due to the high porosity of the fruit peel which permits free water vapor movement (Elyatem and Kader, 1984). Weight loss increased with increasing storage periods.

Table 3. Percentage of weight loss in stored pomegranate fruit during cold storage using solar and electrical energy.

\begin{tabular}{|c|c|c|c|c|c|c|c|}
\hline \multirow[t]{2}{*}{ Treatment (A) } & \multicolumn{2}{|c|}{ Storage } & \multirow{2}{*}{$\begin{array}{c}\text { period } \\
20 \\
\end{array}$} & (days) & \multirow[b]{2}{*}{40} & \multirow[b]{2}{*}{$\mathbf{5 0}$} & \multirow[b]{2}{*}{$\operatorname{Mean}(\mathbf{A})$} \\
\hline & $\mathbf{0}$ & 10 & & 30 & & & \\
\hline Solar energy & 0.0 & 3.93 & 7.93 & 11.06 & 12.86 & 14.97 & 8.457 \\
\hline $\begin{array}{l}\text { Electrical } \\
\text { energy }\end{array}$ & 0.0 & 4.64 & 8.28 & 11.18 & 13.12 & 15.51 & 8.789 \\
\hline Mean (B) & 0.0 & 4.285 & 8.104 & 11.122 & 12.99 & 15.24 & - \\
\hline LSD at 0.05 & & $\begin{array}{l}\text { eatmen } \\
\text { orage } p \\
\text { teracti }\end{array}$ & $\begin{aligned} & =0 \\
\text { riods } & =0 \\
& =0\end{aligned}$ & $\begin{array}{l}046 \\
1812 \\
563\end{array}$ & & & \\
\hline
\end{tabular}

Concerning the effect of the storage period, it was noticed that by increasing storage period, weight losses was gradually increased, the decrease in fresh weight might be attribute to the loss in moisture through transpiration and loss in dry matter content through respiration (Arendse et al., 2014). Regardless, the storage period, it was cleared that solar energy system achieved the lowest value of weight loss $8.457 \%$, compared to cold storage driven by electrical energy $8.789 \%$ with significant affect as shown in table (3).

Interaction results indicated that, a higher value was recorded by using electrical energy in cold storage was $15.510 \%$ after 50 days storage while the weight loss percentage by using solar energy in cold storage was $14.973 \%$, this might be due to high respiration in pomegranate fruit (opera et al., 2008), these result was agreement with (Arendse et al., 2014) who reported that weight loss increased with the increase of storage period.

\section{- Pomegranate fruits hardness}

Table (4) shows the hardness values of pomegranate fruits stored using electrical and solar energy during 50 days. 
Table 4. Hardness of stored pomegranate fruit during cold storage using solar and electrical energy.

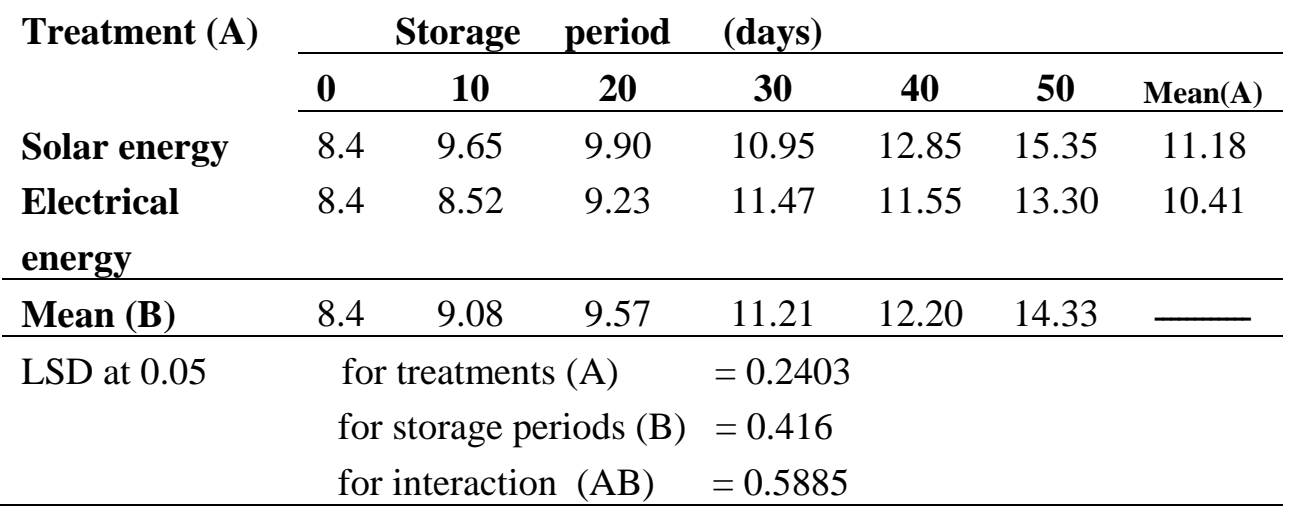

Table (4) cleared that, the cold storage using solar energy gave the highest value of fruit hardness during storage $\left(15.35 \mathrm{~kg}_{\mathrm{f}}\right)$, while the cold storage by electrical energy obtained the lowest ones in this concern $\left(13.45 \mathrm{~kg}_{\mathrm{f}}\right)$.

Regardless, the storage period, it was cleared that solar energy system achieved the highest value of hardness for pomegranate fruits $11.183 \mathrm{~kg}_{\mathrm{f}}$, compared to cold storage driven by electrical energy $10.411 \mathrm{~kg}_{\mathrm{f}}$, with significant affect as shown in table $(\xi)$.

The hardness of pomegranate fruit increased with the increase of storage period, this might be due to the reducing of moisture content during this period and increasing of dry matter content of pomegranate. These results in agreement with observation of Ekrami-Rad et al. (2011) who reported that, the hardness of pomegranate fruits. Holt (1970) reported that several factors affect fruit compression test results; this may depend on the mechanical strength of the skin, firmness of the flesh, Juice viscosity, and size of the fruit.

\section{- Total soluble solid (TSS)\%}

Chemical parameters as total soluble solid (TSS), titratable acidity (TA), and TSS/TA have been used to describe taste (flavor) with regard to the sweetness and acidity; it has been used as a quality criterion for the 
formulation of pomegranate products and its juice (Al-Said $\boldsymbol{e t}$ al., 2009), table (5) shows total soluble solids percentage of stored pomegranate fruit during cold storage using solar and electrical energy.

Table 5. Total soluble solid of stored pomegranate fruit during cold storage using solar and electrical energy.

Treatment Storage Period (days)

(A)

\begin{tabular}{llllllll} 
& $\mathbf{0}$ & $\mathbf{1 0}$ & $\mathbf{2 0}$ & $\mathbf{3 0}$ & $\mathbf{4 0}$ & $\mathbf{5 0}$ & Mean(A) \\
\cline { 2 - 8 } & 15.45 & 15.75 & 14.35 & 15.55 & 15.77 & 17.95 & 15.80 \\
$\begin{array}{l}\text { Solar energy } \\
\begin{array}{l}\text { Electrical } \\
\text { energy }\end{array}\end{array}$ & 15.45 & 17.60 & 13.03 & 14.93 & 15.67 & 17.60 & 15.71 \\
\hline Mean (B) & 15.45 & 16.68 & 13.69 & 15.24 & 15.72 & 17.75 & - \\
\hline
\end{tabular}

LSD at $0.05 \quad$ for treatments $(\mathrm{A}) \quad=0.1281$

for storage periods $(\mathrm{B})=0.2219$

for interaction $(\mathrm{AB})=0.3137$

Table (5) indicted that there were non-significant in the juice chemical properties at both refrigerator are used. The lowest TSS (Brix) content was recorded at initial storage (0 day). Regardless the storage period, it was showed that cold storage using solar energy achieved the highest value of total soluble solid $15.803 \%$, while electrical energy driven refrigerator gave the lowest total soluble solid $15.705 \%$.

TSS increased gradually during storage, the possible reason for the observed increase in TSS contents could be as a result of moisture loss, leading to concentration of sugars inside the fruit. Interaction results indicated that total soluble solid during cold storage for pomegranate by using solar and electrical energy for 50 days were 15.95 and $15.55 \%$ respectively.

These result was in agreement with Arendse et al. (2014) who found that total soluble solid increased with the increase of storage period.

\section{- The cost of cold storage}

The estimated operating cost using EL-Awady equation, for the cold storage using solar energy is about 0.1209 L.E/hr and $0.1478 \mathrm{~L} . \mathrm{E} / \mathrm{hr}$ for cold storage using electrical energy. Therefore, using of solar energy saves cost by $18.2 \%$ according to prices in Egypt during 2016. And in the 
coming years with the increase in the prices of electricity costs and the removal of support it, savings ratio will increase and will increase the demand need for solar energy to use more. And can therefore rely on the use of solar energy instead of electric energy to operate refrigeration unit.

\section{CONCLUSIONS}

The results strongly indicated the effect of cold storage using solar and electrical energy on some physical and mechanical properties of pomegranate fruits through the following marks:

1. Pomegranate fruit stored inside PV driven refrigerator has a good quality than that inside electrically driven refrigerator.

2. The lowest weight loss obtained observed in cold storage using solar energy was $8.457 \%$.

3. The highest TSS and hardness recorded when the pomegranate fruits stored in refrigerator PV driven were $15.803 \%$ and $11.183 \mathrm{~kg}_{\mathrm{f}}$ respectively.

4. The estimated cost of the cold storage using solar and electrical energy is about 0.15 and $0.154 \mathrm{~L}$.E/hour respectively, therefore solar energy achieved the best costs for cold storage using.

\section{REFERENCES}

A.O.A.C. (1995). Official Method of Analysis of Association of Official Agricultural Chemists. $15^{\text {th }}$ ed.

El Awady, M.N.; Abd El-Salam, M.F., Farrag, A.E. and Aboelghait, K.M. (2015). Low quality water treatment and deselimation abased on solar energy technologies. Misr J.Ag. Eng., 32 (2): 909-926 p.

Al-Said, F.A.; Opara, L.U. and Al-Yahyai, R.A. (2009). Physicochemical and textural quality attributes of pomegranate cultivars (Punica granatum L.) grown in the Sultanate of Oman. J. Food Eng. (90):129-134 p.

Arendse, E.; Fawole, O.A. and Opara, U. L. (2014). Influence of storage temperature and duration on postharvest physicochemical and mechanical properties of pomegranate fruit and arils, Journal of Food, 1-10 p. 
Basediya, A.L.; Samuel, D. v. k. and Beera, V. (2013). Evaporative cooling system for storage of fruits and vegetables - a review. J. Food Sci Technol 50(3):429-442 p.

Caleb, O. J.; Mahajan, P. V.; Manley, M. and Opara, U. L. (2013). Evaluation of parameters affecting modified atmosphere packaging engineering design for pomegranate arils. International Journal of Food Science and Technology, (48): 2315- 2323 p.

Darwesh, M. A.; Elmetwalli. H.; Derbala, A.; Fouda, T. and Morad, M. (2010). Manufacture and performance evaluation of solar absorption refrigeration unit for potato storage. Annual conference of the Misr society of Agric. Eng. (28):1907-1921 p.

Ekrami-Rad, N.; Khazaei, J. and Khoshtaghaza, M. H. (2011). Selected Mechanical properties of pomegranate peel and fruit. International Journal of Food Properties, (14): 570-582 p.

Elyatem, S. M. and Kader, A. A. (1984). Post-harvest physiology and storage behaviour of pomegranate fruits. Scientia Horticulturae, (24): 287-298 p.

Fawole, O.A.; Opara, U.L. and Theron, K.I., (2012). Chemical and phytochemical properties and antioxidant activities of three pomegranate cultivars grown in South Africa. Food Bioprocess Technol. (5): 2934-2940 p.

Fawole, O. A. and Opara, U. L. (2013). Changes in physical properties, chemical and elemental composition and antioxidant capacity of pomegranate (cv. Ruby) fruit at five maturity stages. Scientia Horticulturae, (150):37- 46 p.

Hamed, A.H.E. (2013). Prospects of using solar double - effect absorption air conditioning in Egypt. Master of Science in mechanical power engineering. Faculty of Engineering at Cairo University, $142 \mathrm{p}$. 
Holt, C. B. (1970). Measurement of tomato firmness with a universal testing machine. Journal of Texture Studies, (1): 491-501 p.

Horticultural Res. Inst. (2014). Data on pomegranate statistics, Citrus Div., Hort.Res. Inst., A.R.C.

Hussein, Z.; Caleb, O.J.; Jacobs, K.; Manley, M. and Opara, U. L. (2015). Effect of perforation-mediated modified atmosphere packaging and storage duration on physicochemical properties and microbial quality of fresh minimally processed 'Acco' pomegranate arils, LWT - Food Science and Technology 64: 911- 918 p.

Khalil, A. Mubarak, A. Kaseb, S. (2010). Road map for renewable energy research and development In Egypt. University of Cairo, Journal of Advanced Research (1): 29-38 p.

Mphahlele, R. R.; Fawole, O.A. and Stander, M.A. (2014). Preharvest and postharvest factors influencing bioactive compounds in pomegranate (Punica granatum L.)-A review. Scientia Horticulturae 178: $114-123$ p.

Miguel, M.G.; Neves, M.A. and Antunes, M.D., (2010). Pomegranate (Punica granatum L.): a medicinal plant with myriad biological properties. A short review. J. Med. Plants Res. (4):2836-2847 p.

Ngcobo. M. E.K.; Delele. M. A.; Opara. U.L. and Meyer C. J. b. (2013). Performance of multi-packaging for table grapes based on airflow, cooling rates and fruit quality. Journal of Food Engineering (116): 613-621 p.

Opara, L.U.; Al-Ani, M.R. and Al-Shuaibi, Y. (2009). Physicochemical properties, vitamin $\mathrm{C}$ content, and antimicrobial properties of pomegranate fruit (Punica granatum L.). Food Bioprocess Tech. (2): 315-321p.

Qenawy. A. M.; El-Dib. A. F. and Ghoraba .M. M.; (2004). Evaluation and Performance Study of Solar-Powred Einstein Refrigeration Cycle. Canadian Solar Buildings Conference Montreal, August 20$24 \mathrm{p}$. 


\section{الملخص العربيى}

تأثير التخزين المبرد بإستخدام الطاقة الثمسية على جودة ثمار الرمان

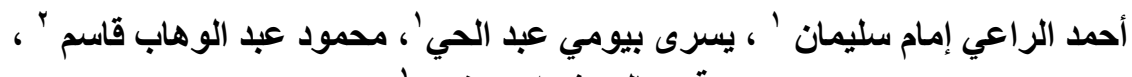

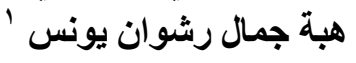

يعتبر محصول الرمان من احد أهم محاصيل الفاكهة فى مصر لمـا لها من استخدمات عديدة

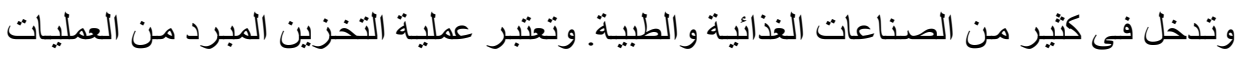

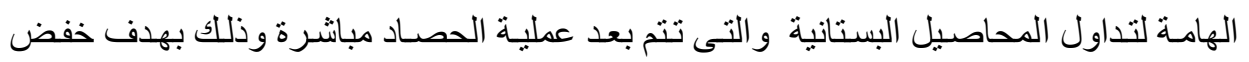

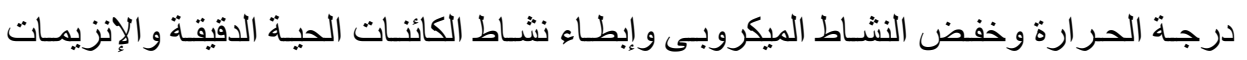

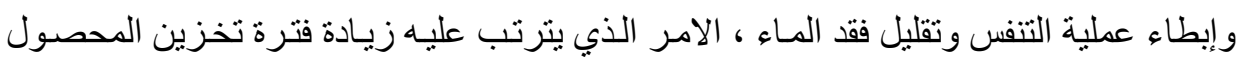

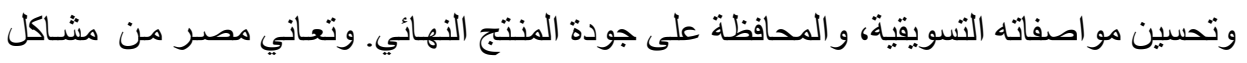

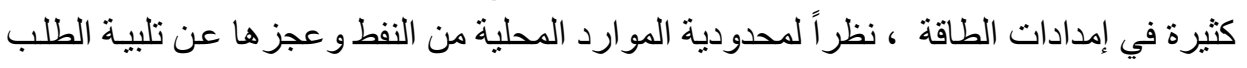

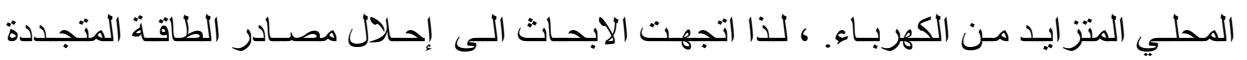

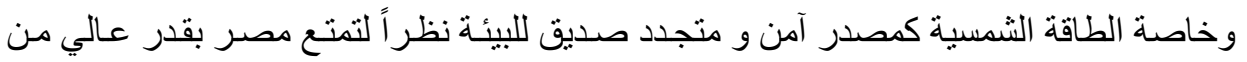

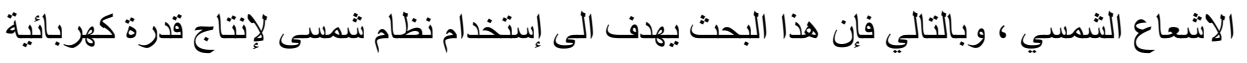

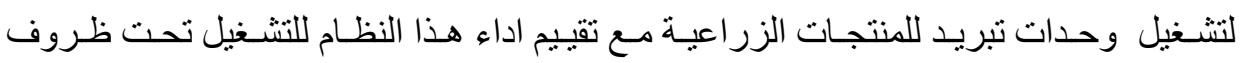

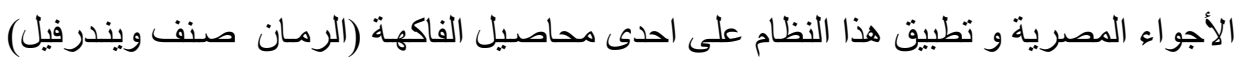

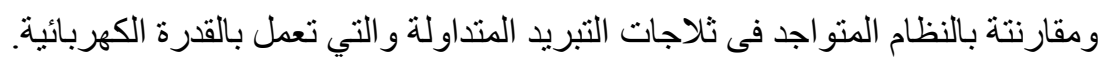

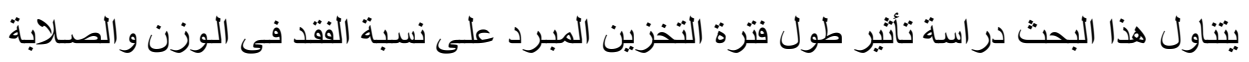

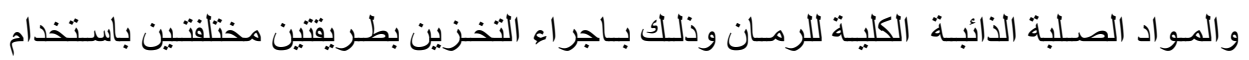

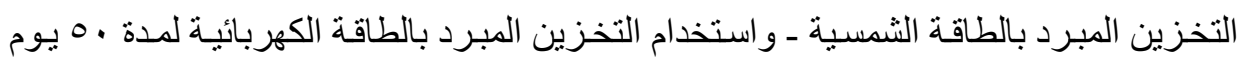

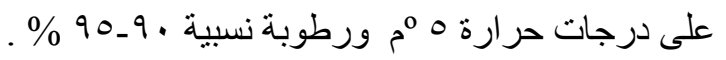

$$
\begin{aligned}
& \text { وكانت أهم النتائج المستخلصة من هذا البحث ما يلي : }
\end{aligned}
$$

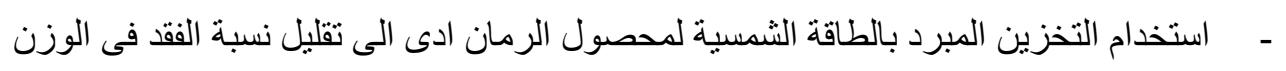

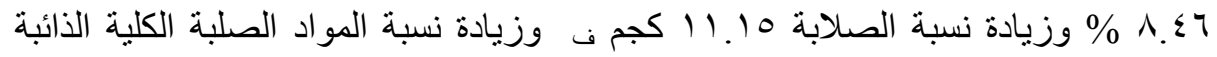

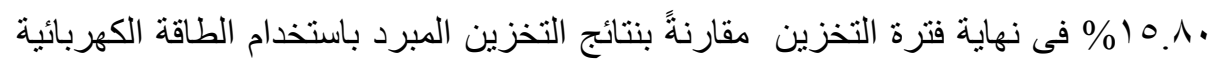

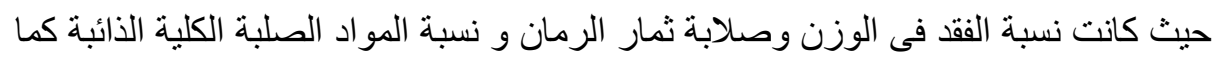

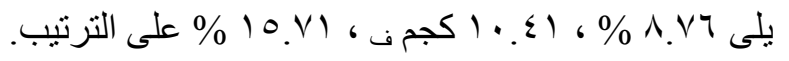

ا. ب. كلية الزر اعة - جامعة القاهرة ـ قسم الهندسة الزراعية

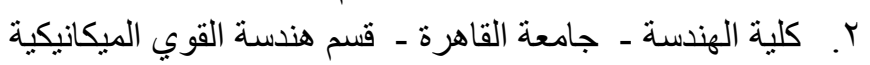




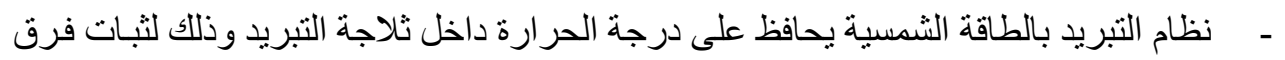

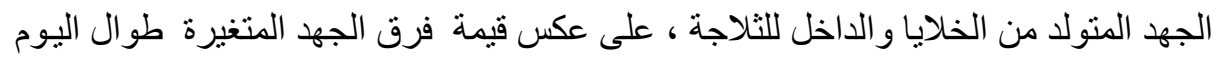
الخارج من الطاقة الكهربائية . الخهائ.

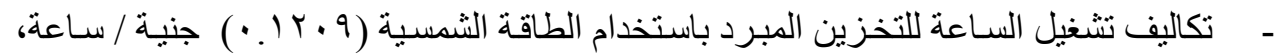

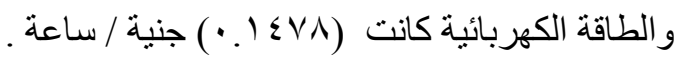

- لذا يوصى البحث بامكانيـة الاعتمـاد على نظام التخزين المبرد بإستخدام الطاقة الثمسية

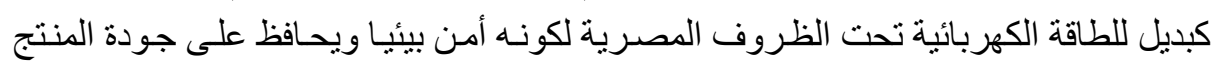

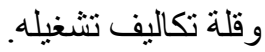

